Breaking the Fourth Wall 


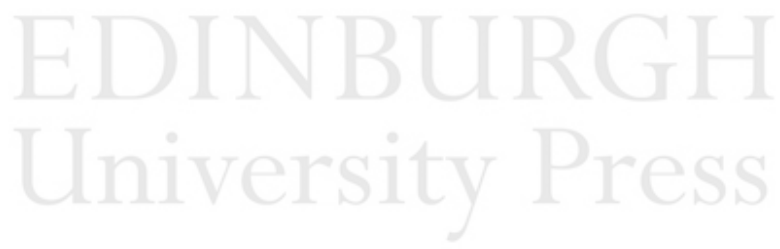

Not for distribution or resale. For personal use only. 


\section{Breaking the Fourth Wall}

Direct Address in the Cinema

Tom Brown 
(C) Tom Brown, 2012, 2013

First published in hardback in 2012 by Edinburgh University Press Ltd 22 George Square, Edinburgh, EH8 9LF www.euppublishing.com

This paperback edition 2013

Typeset in I I / 3 Ehrhardt by Servis Filmsetting Ltd, Stockport, Cheshire, and printed and bound in Great Britain by CPI Group (UK) Ltd, Croydon CRo 4 YY

A CIP record for this book is available from the British Library

ISBN 978 o 748644254 (hardback)

ISBN 978 o 748683079 (paperback)

ISBN 978 o 74864426 I (webready PDF)

ISBN 978 o 74866953 o (epub)

The right of Tom Brown

to be identified as author of this work

has been asserted in accordance with

the Copyright, Designs and Patents Act I988. 